TEME, г. XLII, бр. 4, октобар - децембар 2018, стр. 1161-1177

Прегледни рад

DOI: $10.22190 /$ TEME1804161S

Примљено: 30. 3. 2017.

UDK 378.096:378.147(497.11)

Ревидирана верзија: 18. 10. 2017.

Одобрено за штампу: 12. 6. 2018.

\title{
POSSIBILITIES TO IMPROVE THE QUALITY OF TEACHING AT THE FACULTY OF SPORT AND PHYSICAL EDUCATION IN NIŠ
}

\author{
Zvezdan Savić ${ }^{1}$, Marija Jovanović ${ }^{2 *}$ \\ ${ }^{1}$ University of Niš, Faculty of Sport and Physical Education, Niš, Serbia \\ ${ }^{2}$ University of Niš, Faculty of Philosophy, Niš, Serbia \\ marija.jovanovic@filfak.ni.ac.rs
}

\begin{abstract}
The existing organization and direct implementation of all types and forms of teaching at the Faculty of Sport and Physical Education in Niš certainly provide an opportunity to improve their quality. When a good quality contemporary teaching is mentioned, it is presumed that students are in an active role, and that there are preconditions met for students to be able to participate in the teaching process actively and creatively, while, according to their individual potentials they should be able to progress and develop. In order to systematically present the possible ways to have good quality teaching, this paper provided the theoretical basis and the pedagogical/didactic presentation of two contemporary teaching systems: cooperative and integrative learning. Through the explanation of the essential features of these teaching systems, their values and possibilities, articulation and challenges to implement them, this paper has provided the theoretical concept on how to ensure the quality of teaching through these modern teaching systems.
\end{abstract}

Key words: teaching, university, quality, integrative learning, cooperative learning.

\section{МОГУЋНОСТИ УНАПРЕЪЕЊА КВАЛИТЕТА НАСТАВЕ НА ФАКУЛТЕТУ СПОРТА И ФИЗИЧКОГ ВАСПИТАҢА У НИШУ}

\footnotetext{
Апстракт

Постојећа организација и непосредна реализација свих видова и облика наставног рада на Факултету спорта и физичког васпитања у Нишу свакако пружа могућности за унапређивање њеног квалитета. Претпоставка квалитета савремене наставе јесте субјекатска позиција студената у настави и обезбеђивање услова да у њој студенти активно и стваралачки, сходно својим индивидуалним потенцијалима, напредују и развијају се. Са циљем да се на систематичан начин представе могући начини реализовања квалитетне наставе, у раду је извршено теоријско утемељивање и педагошко-дидактичко представљање два савремена наставна система: коопе-
} 
ративна и интегративна настава. Кроз представљање суштинских обележја ових наставних система, њихових вредности и могућности, артикулације и изазова реализације, у раду је дат теоријски концепт обезбеђивања квалитета наставе путем ових савремених наставних система.

Кључне речи: настава, факултет, квалитет, интегративана настава, кооперативна настава.

\section{INTRODUCTION}

The powerful and rapid development of science and technology, conditioned by the overall expansion of scientific knowledge, presents the modern times with the new, largely altered requirements and standards in all areas. $\mathrm{O}$ ne of the most sensitive areas in which changes in terms of innovation and training are necessary are education and teaching at all levels.

University education and teaching as the backbone of the educational system and the crown of the educational process of the individual, but also the basis of their professional work, must necessarily keep up with the modern development trends and overcome the limitations of the traditional, out-dated and obsolete.

The modern education concept aligned with the Bologna Declaration specifies that the quality of teaching at the universities is a concern and responsibility of certain institutions and individuals: the Ministry, Universities and Vice Deans. In accordance with the abovementioned tendencies, and according to their authority, the Faculty of Sport and Physical Education has only in the last few years started partly working on the internal and external training of assistant professors and professors in order to improve the quality and results of teaching. These activities are undertaken on the basis of the analyses of current needs and are aimed at raising the level of pedagogical, psychological, didactic and methodical education and the development of professional competences of teaching staff. It is also expected that the frequent visits of assistant professors and professors through the "Erasmus" exchange programs will also provide some long-term changes regarding the improvement of teaching quality through the direct application of the acquired knowledge, skills and experience at the international universities. The quality and the outcomes of teaching at the Faculty of Sport and Physical Education, we have to agree, are especially important because future teachers and sports coaches are educated and trained at this faculty. They are trained to unify the education (acquiring knowledge to be transferred to students and contestants) and pedagogical work, that is, the aim is to enable them to link educational and pedagogical components of development into a unified whole (Havelka, 1988). In order to succeed in this, teaching at the faculty must be planned, programmed and implemented in such a way to develop the competences 
of a modern teacher, a sports coach. The main prerequisite for success is securing the active role of students in the classroom and providing the conditions for students to learn, practice and develop through activities and action. The changed role and position of students in the classroom requires teachers and assistants of contemporary pedagogical and didactic/methodical competences who will apply modern methods, teaching models and act from a significantly redefined position. The changed role of teachers implies the use of such teaching systems where students will be active participants, creators, and planners of lessons. The teacher hands over the central, immediate, and active role in teaching activities to the learners and occupies the position of a mediator, assistant, and adviser. Since the integrative and cooperative teaching are modern teaching systems where the direct activity and cooperation allow students to acquire comprehensive, functional knowledge and skills, this paper will deal with theoretical research of the values, roles and possibilities of application of these types of teaching at the Faculty of Sport and Physical Education in Niš.

\section{Possibilities to Improve the Quality of Teaching}

Teaching is a unique education process consisting of three stages: 1) planning and preparation of teaching, 2) actual teaching, and 3) monitoring and evaluation of teaching results (effects of education). Teaching at the faculties should certainly be based on and relied on high school teaching, where it is clearly noticed that students actively study with the help of the Internet, travel and film (Radojičić, Lukić, 2011). At the Faculty of Sport and Physical Education in Niš, at the Academic Studies programs, the following types of teaching are present: theoretical lectures, practical lectures, practical exercises, theoretical exercises, professional practice and interactive teaching. The past efforts of the Vice Dean provided some support for the improvement of teaching. These efforts included: annual school calendar, book of the subjects (syllabus), book of records (classes done), submission of regular reports on classes done with improvement proposals (form created), and also a large library. In order to ensure the good quality of teaching, continuous evaluation and self-evaluation is carried out. Selfevaluation as a "form of the responsibility taken by the faculty and readiness to seek out all the relevant elements for further development" (Stanojević, Zdravković, 2013, p.178) is an integral part of the activities carried out at the Faculty of Sport and Physical Education, which help reveal the deficiencies and possible ways to improve the teaching process. The models that could possibly improve the quality of teaching at the Faculty of Sport and Physical Education are cooperative and integrative learning. 


\section{COOPERATIVE LEARNING \\ AS AN INNOVATIVE TEACHING SYSTEM}

As a type of learning through collaboration and team work, cooperative learning is a particularly appropriate way of learning for the students of the Faculty of Sport and Physical Education. As an "instructional method where the students of different levels of knowledge learn together in small groups" (Miletić, 2007, p. 61), that is, "work together in pairs or small groups to approach a common problem, explore a common topic or build up common knowledge in order to create new ideas, new combinations or unique innovations" (Kurtis et al., 2002, p. 15), this teaching system can be widely applied at the Faculty of Sport and Physical Education.

Cooperative learning is a type of learning where students work together, exchange, but also confront opinions, attitudes, ideas, and achieve the goal of the group through a humane relationship. With its characteristics, cooperative learning provides a quality interaction and replaces the memorization with the creative role, the active role of students who develop their individual potentials, cooperate, engage higher levels of thinking, then, activate the processes such as comparison, explanation, classification, deduction (Suzić, 1999). Working in a group, where everyone is responsible for the results of one's own work, students help one another, they encourage one another, and encourage the activity in terms of thoughtful collaboration.

Cooperative learning means that the student is active both physically and mentally. It is implemented through group work, specifically in small groups. Group work cooperation is different since it requires that the group, as well as each of its members, are asked to independently solve tasks, taking into account their contribution to the success of the group. It "enables individual work according to the capacities of each student, but also affirms learning as a mutual effort in pairs, smaller and larger (research) groups in which knowledge, experiences, skills are developed and the necessity, advantages and preconditions for group work are understood. Adequate activities (perceptive, thoughtful, practical, expressive), interwoven with spontaneous and friendly feelings developed during group work, represent a suitable tool for the students to express their personality, who are in this way given the opportunity to occasionally or more often show their affections and preferences" (Stanojević, 2010, p.116). The goal of this type of learning is to ensure the interdependence of group members, which is the essential prerequisite for ensuring the good quality of teaching. The didactic value of cooperative learning is also important from the aspect of new, different positions and roles of teachers, students and groups who successfully develop cognitive, communicative and social skills. 
The basis for the implementation of cooperative learning is to divide the students into small groups structured in such a way as to be capable to achieve defined goals and defined outcomes. Cooperative learning requires special organization, thorough preparation and teachers with the developed didactic/methodical conscience. The new didactic/methodical teachers' skills are a prerequisite for the successful implementation of cooperative teaching. In cooperative learning process the teacher's role is that of a planner, facilitator, guide, organizer, partner, and evaluator. Teachers' activities involve the division of students into groups, task assignment, and encouraging cooperation among group members, all in accordance with clearly defined qualitative and quantitative criteria (Vilotijević, 2007, p.54).

The size of the group represents a "central tendency" within the quantitative criteria for the implementation of cooperative teaching. The size of the group should be decided upon based on the nature of, specifics and the difficulty of the assignment, and on the individual abilities and personality traits of students. More difficult tasks require a larger group, which is also the case with the students of lower communication and teamwork skills. A well-formed group with the ideal conditions for a successful interaction between the members in order to complete a task is the one that contains five to seven members. Unlike this one, the qualitative criterion implies the homogeneity or heterogeneity of the group, that is, grouping the students based on some common, identical (homogeneity), or different, specific (heterogeneous) characteristics. Teaching practice testifies to a better efficiency of heterogeneous groups because they provide higher quality of work and results that come from more favourable interaction, encouragement and cooperation among group members of different abilities and aspirations. This type of group is especially desirable to have during the motor skills practice classes, and when mastering techniques and skills for individual and team sports. A significant challenge for the didactic/methodical competence of teachers is the understanding of a proper assignment of roles in the group. It is important to keep in mind that the same students should not always be assigned the same roles, but their roles should rather be rotated. Rotation of roles stimulates student motivation and provides a higher level of readiness to invest maximum effort to successfully accomplish the group task.

Successful cooperative teaching requires its implementation in the conditions that are characterized by cooperation and interaction, that is, the conditions in which the students would look at each other's faces rather than the back of their heads. A semi-circular and horseshoe seating or standing arrangement in classrooms or on fields is a prerequisite for successful cooperative teaching. After meeting this requirement, effective implementation of cooperative teaching involves the following four phases:

1) Phase of working with the entire group characterised by the two main activities: introduction of students to the learning topic, goal, 
tasks and expected outcomes and the division of students into groups. The division into groups is done in accordance with the nature of the teaching topic, its scope and complexity, as well as with the individual abilities and interests of students.

2) Phase of group task assignment where the teacher decides whether all groups will get the same tasks, whether each group would get different tasks or different tasks would be assigned within groups (Vilotijević, 2007, p. 57). After assigning group tasks, the teacher gives the students the teaching materials and tools to solve the tasks.

3) Phase of independent student work when they study, analyse and solve the tasks. Every group member actively participates in the completion of his or her part of the task so that, by the end of this phase, they would have all together solved the set task, problem or situation completely.

4) The phase of plenary work when each group presents the solutions to their tasks. At this stage, the most important role is that of the leader of the group who systematically summarizes the work of the group and informs the others about the solution of the assigned task. At this stage the role of the teacher is significantly important since he/she is there to help, guide and systematize the conclusions and integrate them into a whole that should be adopted by all groups.

5) The verification phase is the last phase when implementing cooperative learning. During this stage, the teacher should quickly assess the quality and the level of knowledge acquired and how accurate it is. Depending on the nature of the material taught, various forms of assessment can be used for this purpose: micro verbal and written tests, respondents (in case of theoretical material), or short demonstration of activities (practical material), etc.

The implementation of cooperative learning at universities requires the teachers to be in fundamentally different roles compared to the traditional teaching. The teacher is expected to efficiently: 1) Plan and prepare lessons; 2) Prepare good tasks and provide adequate tools and teaching aids; 3) Get to know the students well, their objective and subjective abilities, interests and needs; 4) correctly form the groups according to the nature of teaching material, quantitative and qualitative criteria; 5) correctly assign the tasks to each group or within a group; 6) properly distribute the roles within groups; 7) monitor, guide and correct group work; 8) encourage students' activity and continuously monitor and evaluate their engagement; 9) assess the progress of each student and inform them about it;10) encourage independent, creative and critical engagement of students during tasks solving; 11) provide the students with the opportunity to independently check the quality of the solutions to their tasks, to assess and critically analyse them; 12) provide feedback on perceived difficulties and obstacles, but also extremely successful steps; 13) motivate and encourage the students in all stages of cooperative learning, etc. 
In order to more fully understand the value of cooperative learning and increase teachers' engagement at the universities, it is necessary to highlight its advantages compared to traditional teaching. Cooperative learning ensures students' activity in the classroom and experiential learning; enables higher level of achievement and more lasting knowledge; provides the opportunity to better master the skills and habits; develops critical thinking, creative and active attitude; encourages self-motivation of students; develops teamwork and cooperative spirit in the classroom; provides an active and positive attitude towards the faculty, teaching, order and discipline; encourages the tolerance and development of other positive social skills; develops responsibility, self-assertion and selfactualization of personality; improves self-esteem; reduces the fear of mistakes and failure, etc. (Kurtis 2002; Vilotijević 2007; Miletić 2007; Džaferagić and Tomić 2012).

Past studies on didactic values and effects of cooperative teaching indicate its positive contribution to the cognitive and socio-emotional personality development and the possibilities to use multiple approaches when applying this type of teaching for various teaching subjects (Simon, 1959; Coppes, 1969; Reić- Ercegovac, Jukić, 2008; Antic, 2010; Kocabac, 2013). When observing the cognitive aspect of achieving the teaching goals, it has been established that cooperative learning has a very positive impact on the development of students' self-learning ability (Buj, 1983), encourages and ensures academic achievement (Johnson, Johnson, 1990), increases the level of reasoning and transfer of knowledge in the classroom (Johnson, Johnson, Holubec, 1993), enables students to self-educate themselves and self-study creatively (Stanojević, 2010) and allows for a more permanent, declarative, procedural and detailed knowledge (MiščevićKadijević, 2009), etc. By studying cooperative learning, it has been found that cooperative learning encourages higher levels of cognitive ability, such as: comparison, contrast, explanation, classification, deduction, etc. (Suzić, 1999).

Mutual co-operation and relationship among the participants in cooperative learning process significantly improve the socio-emotional dimension of education (Hartly, 1976; Schell, 1975, Slavin, 1980; Marantz, 1988). It helps develop better interpersonal and cooperative relations, friendship, mutual respect, moral reasoning, tolerance, assuming the roles responsibly and other types of democratic relations (Ševkušić,1995; Peklaj, 2001). Moreover, regarding emotional and social competences, cooperative teaching develops the ability to recognize one's emotions as well as other people's emotions, self-control, reconciliation, non-violent communication, active listening, negotiation and other socio-emotional skills (Suzić, 1999). Results of the research also show that cooperative teaching provides the following quality indicators: willingness to help and cooperate, friendly behavior, peer acceptance, relaxation and overcoming the fear of negative evaluation and failing in school (Buljubašić-Kuzmanovic, 2009). 


\section{An Example of Cooperative Learning}

As we could see, cooperative learning creates the possibility for active participation of students in the process of knowledge acquisition, skills and habits development and comprehensive knowledge acquisition. Teaching materials specified in the course books at the Faculty of Sport and Physical Education are more than suitable for the implementation of this modern teaching system. In order to carry out the operationalization of knowledge about a cooperative approach in teaching, we will give an example of a teaching topic that can be successfully taught using this approach.

Example \#1. Teaching subject: Olympics- lectures. Teaching topic: "Modern Olympic Games". After the initial introduction of students to the teaching topic, tasks and the goal of the lesson, as well as the expected outcomes, the teacher divides the students into groups. A prerequisite for the successful cooperative learning is the adequate preparation of the teaching material. The material should be able to require students to be fully mentally engaged rather than to simply memorize the material. After the material is handed over to the students, the teacher assigns the tasks. The abovementioned teaching topic can be broken into the following tasks: Group 1: Restoration of the Olympic Games; Group 2: Disciplines and duration; Group 3: Judges and competition facilities; Group 4: Oath, flag and anthem; Group 5: Motto, emblem and symbol.

Example \#2. Teaching subject: Outdoor Activities - lectures. Teaching topic: "Types of outdoor activities". This teaching topic can be divided into the following tasks: Group 1: Field trips; Group 2: Bivouacking; Group 3: Tenting; Group 4: Camping; Group 5: Hunting and fishing; Group 6: Roller skating; Group 7: Rules of behaviour and dangers in nature.

If necessary, the teacher can assign different tasks within a group. The basic criterion for this is the complexity of teaching materials, the ability and the interests of students. During group work, the teacher monitors, instructs, guides and helps out when needed. After the independent work of the group is completed, a plenary presentation by all groups follows that must be supervised and directed by the teacher. It is very important to emphasize the basic key points and the most important conclusions. During the plenary presentation, the teacher must functionally link all the presentations. The end of the cooperative processing of the subject must necessarily contain a verification of achievement. Using a skilful didactic/methodical approach, the teacher seeks itemized summary, or a demonstration of conclusions.

\section{INTEGRATIVE LEARNING AS AN INNOVATIVE TEACHING SYSTEM}

Integrative learning represents the next modern teaching system which can be effectively used at the Faculty of Sport and Physical Education. Focused on the adoption of comprehensive and systematic knowledge and the development of functional abilities by applying experiential, interactive 
and cooperative methods of teaching and learning, integrative learning is one of the most important innovative teaching models. Integrative approach to learning emphasizes intellectual, social, emotional and aesthetic development, supports the comprehensive development and does not focus solely on isolated, cognitive aspects. Through this type of learning, students will prepare themselves for more comprehensive learning, and more appropriate use of knowledge in real life (Radojičić, Lukić, 2011). The following are seen as the main barriers and difficulties for its implementation: it is uneconomical in terms of time, due to the complexity of its planning and implementation (it requires the alignment of curricula, coordination and integration of teaching materials); the understanding that integrated teaching deprives the teacher of the autonomy; insufficient didactic/methodical training of teachers to perform it; training in traditional teaching disciplines and insufficient knowledge of other disciplines; difficulties in coordination among teachers.

The essence of integrative learning is a thematic approach that ensures the link between the related teaching materials from different subjects/courses in order for the students to more comprehensively adopt them and more systematically master them. The integrity, which is achieved through integrative teaching, enables students to integrate, link their knowledge and experiences and thus take on a creative, active stance in the process of teaching and learning as well as in life, sports and at work. The integrative approach in teaching helps adopt comprehensive knowledge and image of reality based on the immediate experience of students. This approach thus provides opportunities for students to develop their cognitive potentials and to achieve deep learning (Bretz Jr \& Thompsett, 1991, p. 941-951), to develop divergent thinking and originality in mastering prescribed teaching material, but also to experience learning in the classroom as a significant component of further learning and education (Bretz Jr \& Thompsett, 1991, p. 941-951). It provides an overview of one problem from several different aspects, which contributes to achieving more sophisticated learning levels (Klein, 2005, p. 8-10), which does not exist when we have strictly divided courses.

The core of integrative teaching involves the development of relationships and links that, based on their character, can be as follows: interdisciplinary direct links, research interdisciplinary direct links, mentally mediated links and mediated applied links (Vilotijević and Vilotijević, 2008, p. 144).

Interdisciplinary direct links relate to the integration where the adoption of some material, activity or process from one school subject refers to the material from another subject. At the Faculty of Sport and Physical Education, the existence of this kind of integrative links is a prerequisite for successful student education. Although it is not achieved through the direct integrative teaching, the minimum degree of existence 
of such links is provided by the prerequisite to take the courses or pass the exams where there is the need to establish these types of relationships and links.

Research interdisciplinary direct links are established when studying and researching one problem requires that problem to be considered from the standpoint of multiple disciplinary approaches.

One problem, phenomenon or activity is approached from the aspect of several related disciplines or subjects in order to make the acquired knowledge or developed skills and habits clearer and extensively perceived.

Mentally mediated links are actually the links where different courses (subjects) can help develop the skills and abilities that the students need in order to be able to do the future jobs and professional activities. For the process of education of the physical education teachers and sports trainers, this kind of relationships and links are of immense importance because they provide a functional link between the teaching activities of various subject teachers all working towards one and the same goal - education and teaching of the physical education teacher/ sports trainer.

The mediated applied links include such a type of integrative linkage which ensures that the knowledge and skills acquired from one teaching subject are directly used and applied in other teaching subjects.

The degree and character of these interdisciplinary relationships and links is caused in real life by the three most common types of integration: complete, partial, and block integration (schedule) (Vilotijević and Vilotijević, 2008, p.147; Drobnjak, 2007, p. 81-91), which would be especially important for the courses at the Faculty of Sport and Physical education.

The prerequisite for a successful integrative teaching at the faculty is planning and flexible timetable, which allows flexibility when deciding upon an adequate timeframe for the successful use of this teaching model.

Block schedule is the most appropriate form of time organization of integrative teaching (Jovanović, Kovčić, 2017). It creates real conditions for the application of all three forms of integration: merging different teaching materials into a single learning course (complete integration); joint processing of teaching material (partial integration) and the creation of autonomous blocks or the separation of common parts within a program that will be integratively processed (block integration).

The didactic value of integrative teaching is reflected in the functionality of the acquired knowledge, skills, and habits, as well as in the competences provided by it. The prerequisite for its successful implementation is integrative thematic planning. Thematic, integrated planning is interdisciplinary and it comes down to the thematic curricula (Vilotijević, 2000). The thematic planning requires all teachers to be involved working towards the ultimate goal of having interdisciplinary studying of 
teaching topics in order to have students adopt comprehensive and extensive knowledge and skills, which should be the end result. Some potential obstacles related to teachers also arise from the requirement for the engagement of all teachers in the planning and implementation of integrative teaching. Integrative teaching requires the following:

1) Didactically and methodically well-trained and skilful teachers who have mastered the skills of thematic planning and implementation of integrative teaching; methods and forms of interactive teaching;

2) Teachers with broad general knowledge, pedagogical knowledge, expert knowledge and knowledge on related disciplines, and who are also very familiar with the school curriculum and teaching programs of the courses being taught in the school;

3) Teachers open to cooperation and team work;

4) Teachers who know the individual capacity of students, working conditions, characteristics of the group, etc.

As it can be seen from the abovementioned, the application of an integrative methodical approach in teaching requires a completely new type of organization and lesson planning. Steps in the planning and implementation process of integrated lessons can be defined differently: the selection of an appropriate topic, identification of the objectives to be met by addressing a particular topic, identification of the order of the goals wanted and concepts to be covered, as well as the planning of the appropriate activities for each topic; selection and preparation of teaching materials needed to cover the selected topic; description of the activities, evaluation and conclusion on the topic covered (Spasić-Stošić, 2016, p. 388-389).

On the other hand, Walsh $(1997$, p. 146) claims that the implementation of integrative planning implies: adequate choice of the appropriate topic, brainstorming of ideas about the topic, adequate knowledge of the topic, gathering materials necessary for the topic, lesson planning. Although the difference between these authors is only in the degree of operationalization of the lesson, what they have in common regarding all the definitions of the integrated planning steps is the emphasis on the experiential and creative effort by students, and on the links with the experience and the independent problem solving.

Thus, the author Buljubašić-Kuzmanović points out that integrative learning at the beginning, during the brainstorming phase should be focused on group work, while later on it should strive towards autonomy and self-responsibility. The lessons based on the integrative approach start from the knowledge that the students already have, from their experiences, and these should be taken into consideration when planning integrated classes. By following the principle from known to unknown, the students develop a feeling of satisfaction because they feel competent at the very beginning of learning which in them creates the need for continuous learning (2007: 147-160). 
Studies within this field of integrated teaching mainly focus on identifying the results of comparative studies which examine how integrated teaching affects learning, students' attitude and behavior. Generally speaking, the results were positive when it comes to all ages and all areas studied, since it has been found that integrated teaching allows the increase in learning outcomes as well as better attitudes towards school, which reflected on students' behavior. Lake (1994) summarizes the results and lists numerous reasons that support integrated teaching. He claims that the main values of integrated teaching are: fostering the ability to apply knowledge, quicker memorization, the acquisition of integrated knowledge which is the result of viewing things from different angles, deeper and broader approach to learning, building positive attitudes towards learning, increasing motivation for learning, etc. (Lake, 1994). Many different studies talk about the positive effects of integrated teaching. The following conclusions have stemmed from the studies of integrated teaching: integrated teaching helps students to apply skills learnt; provides deeper and broader knowledge, promotes positive conduct in students, devotes more time and attention to the study of the most important topics of the curriculum (Lipson, 1993).

More recent studies show that integrated learning allows for active participation, more initiative, adaptability to new scenarios, critical thinking and overcoming learning difficulties (Buljubašić-Kuzmanović, 2007).

Šefer and Radišić (2010) have made significant contribution to the research of interdisciplinarity. Their studies have proven that in teacher's opinion, the interdisciplinary approach to teaching encourages creative thinking and behavior in students. Changes in attitudes, the sense of success and motivation of students and teachers are the most common values of this specific approach to teaching. Moreover, the studies conducted by Radojičić-Lukić (2011) emphasize that integrated teaching has a very positive effect on the creation of an environment that encourages the creativity of students and develops a high level of personal satisfaction when using this teaching model.

Based on the review of the abovementioned studies, we can conclude that the interdisciplinary approach to teaching is immensely important at all levels of education.

The abovementioned values of integrative learning are of particular importance for the physical education and sport studying, because only by ensuring integrity in the education process can the students acquire academic knowledge, practical skills and competencies in order to be able to do their future jobs related to either physical education, training, corrective exercises or exercises for health.

\section{Possible Models of Integration of Teaching Subjects}

In order to operationalize the introduced knowledge about integrative teaching, we will provide some examples of possible integration of teaching 
subjects from the Basic Academic Studies at the Faculty of Physical Education and Sport in Niš. Besides providing the names of the courses we suggest, we will also specify certain teaching topics that integrative approach can be used for:

1) Theory of Physical Education (Basic concepts in the theory of physical education) - Terminology of Physical Education and Sport (The structure of technical language used in physical education);

2) Rhythmics (Artistic dance; Social dance) - Social dance (History of social dance; Modern social dances, etc.) - Dance (Dance and art; Dimensionality of dance; the development of dance; Implementation if dance; Folk dance: Development factors; Types; Forms, styles; ethnocoreological dance areas, etc.);

3) Health education (Nutrition; Nutrition and promotion of healthy lifestyles) - Fitness(Nutrition and exercise) - Hygiene (Nutrition, basic nutrients in nutrition of children and athletes; Nutrition, recommendations for proper nutrition of children and athletes) - Nature activities (Nutrition standards).

4) Anatomy (Heart, Central nervous system, etc.) - Physiology (Physiology of the cardiovascular system; Physiology of the central nervous system, etc.)

5) Anatomy (Arm anatomy; Leg anatomy; Vertebral column anatomy, etc.) - Physiology (Arm physiology; Leg physiology; Vertebral column physiology, etc.) - Biomechanics (Functional anatomy of the arm; Functional anatomy of the leg; Functional anatomy of the vertebral column, etc.);

6) Sport for the Disabled (Rehabilitation; Rehabilitation procedures in working with disabled persons of different ages) - Adapted physical education (The structure of APE programfor people with special need sduring PE lessons and sport practices - Recreation and Kinesitherapy);

7) Biomechanics (Functional anatomy of individual parts of the body: arms, legs, bones, etc.) - Corrective gymnastics (Corrective gymnastics exercises for certain parts of the body: arms, legs, spin, etc.).

As it can be seen, the given models are just some of the examples out of a large number of possible integrated links among the courses from this study program. Within the given models it is also possible to further combine and interconnect them, based on the teaching topics being covered.

\section{CONCLUSION}

Today's modern society is characterized by technological, political and economic changes. Together, these changes put new demands in front of social systems and institutions, including the education process. Education must be understood as the driver of all social changes and improvements, and therefore it is constantly being affected by the 
changes and innovations. Future plans for contemporary education at the universities in Serbia include continuous exponential development and progress under the influence of external factors (technological, economic, cultural and economic changes). Universities must be ready to keep up with and apply all the above changes. The question is just what kind of changes do we want? In general, courses and lessons at the Faculty of Sport and Physical Education must be more flexible and more effective, and students more motivated.

Clearly defined quality standards can improve the quality of the teaching process and this needs to be worked on perpetually. The quality of the teaching process at the Faculty of Sport and Physical Education in Niš is ensured by applying the following standards: a) quality of course plans, b) quality of teaching, c) quality of textbooks, d)quality of evaluation, and e) quality of pedagogical work of teachers and assistant teachers. The main purpose of the Course Plan is to inform the students about the teaching subject and to provide the basis for a systematic and planned approach to the teaching process. The quality standards of teaching (lectures, practical exercises) include: the control of lectures and practical exercises according to the Course Plan; control of the lectures and practical exercises and the objective evaluation of knowledge. The quality of textbooks and the quality of evaluation are also integral parts of the quality of teaching (Rulebook - document, 2016).

In accordance with the Bologna process, and in order to provide higher quality of theoretical and practical teaching at the Faculty of Sport and Physical Education, it is necessary to achieve the following goals in the following period: 1) modernize the teaching process by introducing interactive/participatory methods ("interactive teaching platform"), 2) change the position of teachers and students in the teaching process, 3) provide interdisciplinary links and adoption of teaching material, 4) increase the focus on interculturality and critical thinking among students in theoretical education, and 5) create and establish a partnership with the broad social community.

Starting from the aforementioned concept of quality assurance, this paper has provided the theoretical foundation of cooperative and integrative learning as the teaching systems that can be used to fulfil this quality vision at the Faculty of Sport and Physical Education. As stated in this paper, the quality vision of teaching is materialized through these teaching systems as follows: with thoughtful and practical engagement in teaching, group work, interaction in the classroom, collaboration and cooperation, creative engagement in problem solving, competitive spirit, creative and activist attitude, integrity and functionality of knowledge, experiential learning, deep learning, etc. 


\section{REFERENCES}

Antić, S. (2010). Kooperativno učenje: modeli, potencijali, ograničenja [Cooperative Learning: Models, Potentials, Limitations]. Beograd: Institut za psihologiju Filozofskog fakulteta.

Bretz Jr, R. \& R. Thompsett. (1992). Comparing traditional and integrative learning methods in organizational training programs. J. Appl. Psychol, 77, 941-51.

Buj, M. (1983). Odgojno-obrazovni rad u parovima [Paired learning and education]. Zagreb: Školska knjiga.

Buljubašić-Kuzmanović, V. (2007). Studentska prosudba učinkovitosti integrativnog učenja [Students' assessment of the effectiveness of integrative learning]. Odgojne znanosti, 9(2), 147-160.

Vilotijević, M. (2000). Didaktika 3: Organizacija nastave [Didactics 3: Organization of Teaching]. Beograd: ZUNS.

Vilotijević, N. (2007). Saradnička (kooperativna) nastava [Cooperative (collaborative) learning ]. Obrazovna tehnologija, 1-2, 44-63.

Vilotijević, M. And N. Vilotijević. (2008). Inovacije u nastavi [Innovations in teaching]. Vranje: Učiteljski fakultet.

Drobnjak, N. (2007). Integrativna nastava [Integrative teaching]. Obrazovna tehnologija. 1-2, 81-91.

Jovanović, M., Kovčić, V. (2017). Savremeni izazovi integrativne nastave [Contemporary Challenges for Integrative Teaching]. Sinteze, No.11, 39-71.

Johnson, D. \& R. Johnson (1990). What is cooperative learning, in M. Brubacher, R. Payne \& K. Rickett: Perspectives on small group learning, Rubicon Publishing Inc; 55-68.

Johnson,., R. Johnson \& E. Holubec (1993). Circles of learning: cooperation in the classroom. Minnesota: International Book Company.

Klein, J. T. (2005). Integrative learning and interdisciplinary studies. Peer Review, $7(4), 8-10$.

Kocabaş, A. (2013). The Effects of Cooperative Learning on Continual and State Anxiety and Musical Performance in Teaching Music. International Journal of New Trends in Arts, Sports \& Science Education, Vol. 2, No. 2, 27-35.

Coppes, K., H. (1969). Partnerarbeit im Unterrichtsgeschehen der Grund - und Hauptschule. Frankfurt: Beltz.

Kurtis, S. et al. (2002). Kooperativno ucenje, Vodici [Cooperative Learning, Guidelines]. Sarajevo: Centar za obrazovne inicijative Step by Step.

Lake, K. (1994). Integrated curriculum, School improvement research series. Portland: Northwest Regional Educational Labaratory.

Lipson, M.; Valencia, S.; Wixson, K.; and Peters, C. (1993). Integration and Thematic Teaching: Integration to Improve Teaching and Learning. Language Arts 70/4, 252-264.

Marantz, M. (1988). Fostering prosocial behavior in the early childhood classroom: Revien of the research. Journal of Moral Education, Vol. 17, No. 1, 27-39.

Miletić, J. (2007). Kooperativna ili saradnička nastava [Cooperative or Collaborative learning]. Obrazovna tehnologija, 3, 60-74.

Miščević-Kadijević, G. (2009). Kooperativni pristup u nastavi i trajnost učeničkih znanja [Cooperative approach to teaching and sustainability of students' knowledge]. Nastava i vaspitanje. vol. 58, br. 4, 499-508.

Miščević-Kadijević, G. (2011). Istraživanja postignuća učenika posredstvom kooperacije [The research of students' achievements through cooperation]. Inovacije u nastavi - časopis za savremenu nastavu, vol. 24, br. 3, 131-136. 
Pravilnik o standardima $i$ postupcima za obezbedjenje kvaliteta [Rulebook on standards and procedures for quality assurance].(2016). Niš: Fakultet sporta i fizičkog vaspitanja.

Peklaj, C. (2001). Sodelovalno učenje ali Kdaj več glav več ve. Ljubljana: DSZ.

Radojičić, Lukić, Z. (2011). Interaktivna nastava u savremenom obrazovnom procesu [Interactive learning in the contemporary teaching process]. Obrazovna tehnologija, (4), 367-378.

Reić-Ercegovac, I., Jukić, T. (2008). Suradničko učenje u razrednoj nastavi [Cooperative learning approach in class teaching]. Život $i$ škola, $69-80$.

Slavin, R. (1980). Cooperative learning. Revien of Educational Research, Vol. 50, No. 2, 315-342.

Spasić-Stošić, A. (2016). Uloga školske biblioteke u realizaciji integrativne nastave u osnovnoj školi [The importance of school library for integrated teaching in elementary schools]. Godišnjak pedagoškog fakulteta u Vranju, 7, 381-392.

Stanojević, D. (2010). Socijalna samoevaluacija učenika u svetlu nastavnih situacija saradničkog učenja [Social self-evaluation of students in the light of teaching methods of collaborative learning]. Godišnjak Učiteljskog fakulteta u Vranju, $1,111-131$.

Stanojević, D., and Zdravković, D. (2013). Škola i društvene promene [School and Social Changes]. Novo Mesto: Pedagoška obzorja.

Simon, A. (1959). Partnerschaft im Unterricht. Munchen.

Suzić, N. (1999). Interaktivno učenje [Interactive learning]. Banja Luka: Teacher's Training Center. 77

Schell, Ch. (1975). Partnerarbeit im Unterricht. Munchen, Basel.

Havelka, N. (1988). Psihološke osnove grupnog rada u vaspitanju i obrazovanju [Psychological foundation of group work during the teaching process]. Beograd: Naučna knjiga.

Hartley, W. (1976). Prevention Outcomes of Small Group Education with School Children: An Epidemiologic Follow Up of the Kansas City School Behavior Project. Unpublished manuscript, University of Kansas Center.

Džaferagić-Franca, A., Tomić, R. (2012). Kooperativno učenje u nastavi mlađih razreda osnovne škole [Cooperative learning with younger elementary school students]. Metodički obzori, 7 (2), 107-117.

Šefer, J., Radišić, J. (2010). Kreativnost i interdisciplinarnost u našoj nastavi [Creativity and interdisciplinarity in our teaching process]. Nastava $i$ vaspitanje, vol. 59, br. 2, 205-223.

Walsh, K. V. (1997). Stvaranje razreda usmjerenih na dijete [Creating child-centred lessons]. Zagreb: Udruga Korak po korak. 


\title{
МОГУЋНОСТИ УНАПРЕЪЕЊА КВАЛИТЕТА НАСТАВЕ НА ФАКУЛТЕТУ СПОРТА И ФИЗИЧКОГ ВАСПИТАЫА У НИШУ
}

\author{
Звездан Савић ${ }^{1}$, Марија Јовановић ${ }^{2}$ \\ ${ }^{1}$ Универзитет у Нишу, Факултет спорта и физичког васпитања, Ниш, Србија \\ ${ }^{2}$ Универзитет у Нишу, Филозофски факултет, Ниш, Србија
}

\begin{abstract}
Резиме
Обезбеђивање и унапређивање квалитета наставе императив је и један од најважнијих циљева свих високошколских установа. Претпоставка њиховог остваривања јесте квалитативно измењен приступ улози и позицији студента у настави, и то у смислу обезбеђивање субјекатске позиције и стварања услова да студенти уче, вежбају и развијају се кроз непосредну активност и рад.

Полазећи од наведене концепције обезбеђивања квалитета, у раду је извршено проучавање педагошких и дидактичко-методичких могућности примене савремених наставних система: кооперативне и интегративне наставе, на основним академским студијама Факултета спорта и физичког васпитања у Нишу.

Визију квалитета наставе ови наставни системи, као што се у раду може видети, остварују путем мисаоног и практичног ангажовања у настави, групног рада, интеракције у настави, заједништва и сарадње, креативног ангажовања у решавању проблема, такмичарског духа, стваралачког и активистичког става у настави, целовитости и функционалности знања, искуственог учења и рада, дубинског учења и сл. У раду се зато теоријско утемељивање наведених система остварује кроз представљање суштинских обележја ових наставних система, њихових вредности и могућности, артикулације и изазова реализације у непосредној наставној пракси.

$\mathrm{C}$ циљем да извршимо операционализацију знања о кооперативном приступу у настави, у раду су дати примери наставних тема које се могу успешно реализовати овим приступом. Дати су примери кооперативног приступа у предметима Олимпизам - предавања, настава тема: „Модерне Олимпијске игре” и Активности у природи - предавања, настава тема:„Модели боравка у природи”. Наведени примери пружају могућност да се користе као модели за планирање и реализовање кооперативне наставе и у другим наставним предметима.

Операционализација знања о интегративној настави извршена је кроз седам примера могуће интеграције наставних предмета и спецификацијом појединих наставних тема које се у оквиру ових примера могу успешно остварити интегративних приступом. Као један од примера интеграције може се истаћи пример повезивања следећих предмета: Здравствено васпитање (Исхрана; Исхрана и промоција здравих стилова живота) - Фитнес (Исхрана и вежбање) - Хигијена (Исхрана, основне хранљиве материје у исхрани деце и спортиста; Исхрана, препоруке за правилну исхрану деце и спортиста) - Активности у природи (Нормативи и стандарди исхране). Овај, као и остали представљени примери, представљају моделе могућег остваривања међупредметне интеграције, којом се обезбеђује целовитост и функционалност усвојених знања и вештина као један од основних квалитета савремене наставе.
\end{abstract}

